\title{
Transformation of the global energy resources market as a challenge for Russia's energy security
}

\author{
$E V$ Demidova* and $V V$ Avilova \\ Department of Economics, Kazan National Research Technological University, 68 K. Marx Street, Kazan, Russia
}

\begin{abstract}
We have analyzed the main trends of development of the global energy resources market, as well the positions of countries and major companies that have influence on global energy security. It also considers principal threats and prospects of preserving the national energy security of Russia.
\end{abstract}

\section{Introduction}

The vast contents of energy resources in certain countries and their absence in other ones have always been the primary reason for major international conflicts and contradictions between enterprises that have power in the global market of fuel and energy resources and that mostly define energy security in the world and in certain states.

The unfolding situation with the hydrocarbon energy sources is also typical for other (strategically important) natural resources, mainly for ores of nonferrous, rare and precious metals and certain non-metallic minerals [1]. In the mid-20th century there was a certain set of enterprises that played the main role in the global energy resources market. However, in the late 20th - early $21 \mathrm{st}$ centuries completely different players entered the arena.

When in the 1990s Russian oil and gas enterprises as well as manufacturers of gas and petrochemical products were in a state of consistent decline, few people could predict that literally after a decade the situation would dramatically change, and Russia would be able not only to retain its leading position in the global fuel and energy market but would also assume the role of a key - global - supplier of energy and the guarantor of energy security [2].

This allows us to take a look at the modern problems of energy security in the world and in Russia in particular from a totally new perspective. Taking this into consideration, we have set the following goals in our study:

- to identify the global trends that will influence the development of global power engineering and energy security in the world and in Russia in particular, in the immediate future;

- to examine the role of both traditional global corporations and "new players" that influence the balance of power in the global economy and energy space;

- to analyze the role of Russia as a guarantor of global energy security;
- to identify the primary threats and prospects of ensuring the national energy security of Russia.

\section{Analysis of most significant trends of the global energy resources market}

Global energy security, as well as energy security at the state-wide, region-wide and even company-wide level requires continuous monitoring of both the current state and the future development of the global fuel and energy complex, analyzing its external economic relations, as well as the impact that the functioning of fuel and energy enterprises might have on the environment [3]. It is not advisable that our country ignores these trends either. Instead, it should probably steadily keep track of any slightest changes in the energy policy of the leading global powers, international organizations and major corporations that directly or indirectly influence the energy security of Russia. In this regard, of much interest is the forecast of the world trends, which, as it is expected, will influence the global energy development and energy security in both the world at large and Russia in particular. These trends have been examined in detail in the "Forecast of Scientific and Technological Development of the Fuel and Energy Complex of Russia for the Period up to 2035" [4], developed by the Ministry of Energy of the Russian Federation. The most important of these are as follows:

1. Reduction of energy intensity of the global economy growth. While previously we saw a direct correlation between the growth rate of the world economy and population and the growth rate of energy demand, today this has changed, and, according to the estimates made by analysts in the Ministry of Energy of Russia, the global demand for energy commodities is going to grow slower than the global economy itself [4].

2. Transformation of the global trade using energy resources, including changes in the global demand for energy. On the one hand, it is expected that we will see stagnation of demand for energy in Europe, North America, Japan and South Korea, but on the other hand

* Corresponding author: lipl-alena@yandex.ru 
one can anticipate intense growth in the Asian region (where, according to experts, $60 \%$ of the global demand is going to be concentrated), as well as in the countries of Africa, Latin America and the Middle East [4, 5]. At the same time, it is believed that the current primary manufacturers of energy materials (Saudi Arabia, USA, Russia, Qatar, Kuwait, Nigeria, Venezuela, Canada, China) will retain their leading positions and will be joined by the countries that are actively developing export industries of their fuel and energy sectors (Australia, Brazil, Iraq, Iran).

3. Shift in the global fuel and energy balance and increase of the competition between various fuels $[4,5]$. According to the forecast of the International Energy Agency (IEA), by 2040 oil, gas, coal and low-carbon energy sources will have almost equal shares in the structure of the global energy market (about 25\% each) [6].

4. Growth of the importance of electrical energy in the global economy and industry (particularly in the light of the geopolitical events of the last few years) as the main source of ensuring various countries' energy stability and security.

5. Formation of the so-called "new power engineering", which is based on the introduction and use of alternative means and technologies of power production - mainly by using renewable energy sources, distributed generation, intellectualization (e.g. smart cities); development of energy-efficient technologies in the industrial, transport and housing and utility spheres [4].

6. Tightening of economic and geopolitical conditions of development of oil and gas enterprises. This is due to the fact that the global oil industry and the industry of oil services are to a significant degree monopolized by a few global transnational corporations (GTCs). As a result of this, the situation on the global fuel and energy market to a large extent depends on the policy adopted by a limited number of corporate players [7].

During the last 10-15 years, the structure of the global energy market has become significantly more complex. The aspiration of a lot of countries to regional energy integration and the creation of various integrative entities as guarantors of energy stability and security turned out to be not as effective and reliable as had been expected. This became particularly evident in the recent years in European countries, which cannot arrive to a consensus when making decisions connected with following the interests of certain countries that consume energy resources. However, in spite of this, almost all global energy decisions are still influenced by rival players, including the major oil companies and petrochemical corporations of the world.

\section{The place of traditional global corporations and "new players" in the world's energy space}

In the 1950-70s there were the so-called "Seven Sisters" that dominated the global energy market, and these included the following corporations: British Petroleum (UK); Royal Dutch Shell (Netherlands, UK); as well as American companies Gulf Oil, Chevron, Exxon, Mobil Oil and Texaco. In the 1960s the situation began to change: as a result of excess supply of oil in the global market and political discord among the countries of Europe and the Persian Gulf, OPEC was created; major oil-producing countries (Venezuela, Iraq, Iran, Saudi Arabia) began to nationalize their oil reserves and create government-owned corporations. So, the "new Seven Sisters" emerged and quickly gained a lot of influence, and these new "Seven Sisters" are radically different from the "Seven Sisters" of the 1950-70s [8]. The companies usually named among them are: CNPC (China), Gazprom (Russia), NIOC (Iran), Petrobras (Brazil), PDVSA (Venezuela), Petronas (Malaysia), Saudi Aramco (Saudi Arabia).

At the same time even today the list of the leading players in the global fuel and energy market invariably includes the largest oil, gas and energy enterprises from among the old "Seven Sisters". These are the so-called Big Oil sextet, which includes BP (UK), Shell (UK, Netherlands), Total (France), Eni (Italy), Exxon Mobil and Chevron (USA).

According to the data of annual financial reports of these companies, their aggregate production of oil in 2017 amounted to $11.76 \mathrm{mln}$. barrels/day (compare: Russia produced $10.3 \mathrm{mln}$. barrels/day, Saudi Arabia $10 \mathrm{mln}$. barrels/day, USA - $9.4 \mathrm{mln}$. barrels/day). In natural gas production the Big Oil companies (411 bln. cubic meters) was only behind the USA (760 bln. cubic meters) and Russia (694 bln. cubic meters) [7, 9]. But despite the fact that today these major fuel and energy giants produce more oil and gas than anybody else, they no longer have the same amount of control over the oil reserves as the "Seven Sisters" did. It is the control over the reserves that allowed these companies to influence not only their competitors but entire countries. According to some estimates, the old "Seven Sisters" controlled $85 \%$ of the world's oil reserves, while the six Big Oil companies only control 10\% [9]. Besides, the global energy market has recently been joined by a number of smaller companies that produce tight oil and shale gas and that have substantially affected the global prices of traditional energy supplies and the balance of power in their production.

Consequently, as a result of the transformations happening in the global fuel and energy market (when the significance of traditional types of energy supplies is reduced against the backdrop of active development of tight oil and shale gas and when the role and use of alternative energy sources and more environmentallyfriendly types of energy increases), the role of traditional global corporations and their influence on the power balance in the global economic and energy spaces is changing substantially.

However, despite the aforementioned circumstances, cooperation with Big Oil remains a priority for a lot of the companies of the world's fuel and energy sector, including the leading Russian corporations, because this cooperation is a way to obtain investments and technologies that our country does not possess. The 

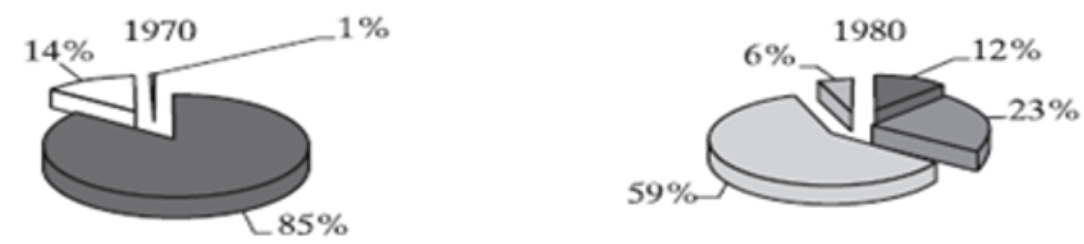

NOGC - national (government-owned) oil and gas companies

IOGC - intemational oil and gas companies

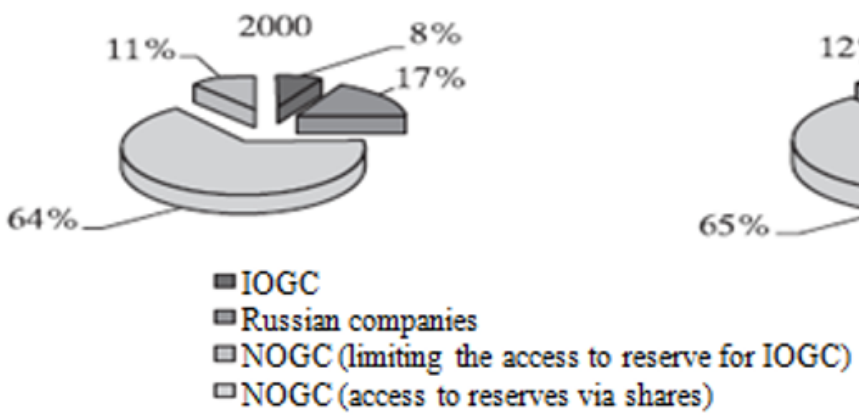

Fig. 1. Access to the global oil and gas reserves in 1970s-2000s [9].

examples of this are the already implemented large-scale projects Sakhalin-I (Rosneft and Exxon Mobil), Yamal LNG (NOVATEK and Total); development and implementation of projects in the Bazhenov Formation and ocean shelves $[7,8,9]$.

In general the current trend is such that it is not transnational corporations but national energy companies that dominate the global fuel and energy market (Figure 1). What is specific about this situation is that the national ownership of resources becomes an important geopolitical influence factor. And, in order to preserve their energy security and economic security, national government-controlled companies simply deny access to the resources of their countries for independent manufacturers [9].

In the conditions of such limited access one cannot really speak about global energy security in the same sense that was meant by it in the 1970 s. In the future the role of national energy companies is only expected to grow. And this will only further aggravate the competition, as well as the economical and political risks [11].

In general, according to the forecasts of experts and analysts, the structure and development of the global fuel and energy market, at least over the next decade, will be defined by several players: USA as a potential exporter; China as the primary manufacturer of goods and products for the global market; Russia as the global provider of energy security for the countries of Europe and Asia [9, 11, 12, 13].

\section{Conclusion}

The changes that are happening recently in the global fuel and energy sector (volatility of international oil prices, growth of geopolitical instability, mutual sanctions imposed by countries on each other) demonstrate that the top position among the defining long-term factors of development is occupied by technologies rather than resources, while the size and quality of the resources themselves take a back seat. Moreover, technological development has become a sign of not just major corporations but small local companies as well, provided that they have an access to the relevant technological tools.

This will not only have decisive influence on the offer in the markets of energy supplies but may also become the main factor of intensified competition in these markets [3]. Even now this is expressed in the changes in the traditional fields of the fuel and energy complex (the "tight oil revolution", LNG), in the formation of the "new power engineering", which is based on renewable energy sources, distributed generation, intellectualization, as well as in the development of energy-efficient technologies in the industrial, transport and housing and utility spheres [14].

In this regard Russian companies of the fuel and energy sector will be exposed to high risks if their development strategies are not defined by their orientation on technological improvement but instead by their exclusive access to the resource base combined with a limited number of large-scale projects, whose high expenses are only covered as long as there is a favorable price environment in the global energy supplies markets $[14,15]$.

However, in spite of the emerging threats, the changes that are happening in the global energy markets create new prospects of development for the Russian fuel and energy complex as well, the most important of such prospects being:

- competitive growth of the Russian economy, accelerating its diversification, growth of the export of fuel and energy resources due to the emerging role of 
quality use of measures of increasing energy efficiency [2];

- modernization of the fuel and energy complex of Russia while using the significant potential for increasing energy efficiency in the industrial, housing and transport sectors, in the sectors of centralized heat supply and production of electrical energy (and in most of these sectors this can be achieved at relatively low expenses) [12];

- the possibility of a substantial growth of export supplies of natural gas and coal to the countries of the Pacific Rim due to them reaching the limits of their own coal production, which will also create additional upward pressure on the prices;

- development of material-intensive and energyintensive productions in Russia, including joint ventures with foreign companies;

- stimulating economic growth and ensuring energy security (particularly in faraway regions of the country) by developing renewable energy sources in the country.

Therefore, while historically ensuring energy security of the state meant merely maintaining continuous access to energy resources (where the key role was played by transnational companies), today the problem of energy security requires complex approach to its research and has the economic, political, environmental and technological aspects. This is why Russia, having enormous energy (including hydrocarbon) potential and playing an important role in ensuring global energy security, must be ready for the qualitative shift in the energy supply system that the world is on the verge of.

\section{References}

1. E.V. Demidova, The Place and the Role of Energy Security in the Modern World: Theoretical Aspects , Journal of Economy and Entrepreneurship, 11,1197-1203 (2017)

2. E.V. Demidova, Market Transformation of Energy Resources: Global Trends and Russian, Realities Kazan Science, 10, 25-8 (2016)

3. Yu.A. Ershov, Global Energy Security and Russia's Interests, 230 (2009)

4. A.V. Novak, Forecast of Scientific and Technological Development of the Fuel and Energy Complex of Russia for the Period up to 2035, 111 (2016)

5. A.V. Novak, On the Main Issues of Development of the Fuel and Energy Complex at the Present Stage, Presentation of the Ministry of Energy of the Russian Federation for the Report of A V Novak to the Federation Council (Electronic Materials) ed Ministry of Energy of the Russian Federation, 39 (2017)

6. E.D. Belotskaya, or Eds A.A. Makarov, L.M. Grigoriev, T. A. Microva, Forecast of Development of Global and Russian Energy 2016 ERI RAS-ATS under the Government of the Russian Federation, 196 (2016)

7. E.V. Demidova, V.V. Avilova, New Trends in World Energy Security: Global Players and Priority
Changes Actual Issues of Economic Security, Collection of Scientific works of the 1st Russian Scientific-Practical Conf. of Students or Eds V.V. Avilova and K.A. Grandonyan, Postgraduates and Young Scientists, 72-9 (2018)

8. V.V. Avilova, E.N. Porfiryeva, Strategic Competitiveness of Russian Oil and Gas Companies, Bulletin of Kazan Technological University, 20, 280-3 (2014)

9. E.A. Telegina, World economy and international relations, New Dimension of Global Energy Security, 11, 5-16 (2015)

10. E. V. Demidova, V.V. Avilova, Energy Security: Challenges, Risks and Prospects, Kazan National Research Technological University Press, 103 (2018)

11. E. V. Demidova, V.V. Avilova, Fuel and Energy Complex as a Factor of Economic Safety of the State Economic Development in the 21st Century: Trends, Challenges and Prospects, Collection of Scientific Works of the 6th Int Scientific-Practical Conf. of Students, Postgraduates and Young Scientists "Horizons of Russia"or Eds V.V Avilova and R.S. Dzarasov, 350-3 (2018)

12. International Energy Outlook 2016, U.S. Energy Information Administration, 276 (2016)

13. O.B. Lomakina, Strategic Interests of Russia in the Field of International Energy Security M.I.R., Modernization. Innovation. Research, 4 ,25-34 (2016)

14. E.V. Demidova, Key Factors of Competitiveness and the Main Directions of Development of the Petrochemical Industry: Global Experience and Russian Trends, Bulletin of Kazan Technological University, 15, 395-400 (2014)

15. The Draft Energy Strategy of the Russian Federation for the Period up to 2035, Minenergo of Russia, 78 (2017) 